\title{
A new geographic record of the endangered Telmatobufo venustus (Amphibia: Calyptocephalellidae) in the Biobío Region, Chile
}

\author{
Helen Díaz-Páez ${ }^{1 *}$ (i) and Nicza Alveal ${ }^{1,2}$
}

\begin{abstract}
We document the record of Telmatobufo venustus Phillipi (1899) in the Altos de Malalcura sector, Antuco, Biobío Region, Chile. This is the first record metamorphic Gosner 45 stage and the fourth georeferenced record of the species throughout its distribution. The data extend the presence of the species in the Biobío Region by more than $100 \mathrm{~km}$, extending T. venustus to north of the Ralco Reserve. The presence of three metamorphic stage individuals and their coexistence with Alsodes sp. in this locality stands out.
\end{abstract}

Keywords: Sapito hermoso, Altos de Malalcura, Biobío region

The genus Telmatobufo Schmidt 1952 is a group of endemic toads of the temperate central southern Chilean forests $\left(35^{\circ}-41^{\circ} \mathrm{S}\right)[1]$ with few records on their distribution range. Cuevas 2010 [2] identified an allopatric distribution for each of the four Telmatobufo species: $T$. australis Formas 1972 has been documented in temperate Nothofagus forest both in the Andes and in the Coast Range (ca. $41^{\circ}-39^{\circ}$ S); T. bullocki Schmidt 1952, microendemic in the forest of the Nahuelbuta (coastal) Range (ca. $37^{\circ}-38^{\circ} \mathrm{S}$ ); T. ignotus is only known from its type locality of Reserva Nacional Los Queules and T. venustus (Philippi 1899) would be endemic to the Andean hygrophyte forest of central Chile (ca. $35^{\circ} 28^{\prime}-37^{\circ} 47^{\prime} \mathrm{S}$ ).

Telmatobufo venustus was initially described in the Cordillera de Chillán [1], but has not been reported again in this area [3]. Therefore, its distribution would be restricted to only four locations on the western slopes of the Chilean Andes from $35.28^{\circ}$ to $38.5^{\circ}$ between 1500 and 1700 m elevation: Parque Nacional Radal Siete

\footnotetext{
*Correspondence: hediaz@udec.cl

'Laboratorio de Ecofisiología y Conservación de Herpetozoos, Departamento de Ciencias Básicas, Escuela de Educación, Universidad de Concepción,

Campus Los Ángeles. Casilla 341, Los Ángeles, Chile

Full list of author information is available at the end of the article
}

Tazas (Maule Region) [4], Altos de Vilches (Maule Region) [5], Cordillera de Chillan (Nuble Region) [6] and Ralco (BioBío Region) [7],

Chile mountain false toad inhabits clean, welloxygenated waters in temperate Nothofagus (southern beech) forests with $N$. obliqua (roble), Gevuina avellana (avellano), Lomatia hirsuta (radal) and understory of Drymis winteri (canelo), Fuchsia magellanica (chilco) and Chusquea quila (quila) [8]. The adults are found under trunks and stones on the edges of mountain streams or within them [1].

There is little information about the biology of this species, and there no records of metamorphic, postmetamorphic or subadult individuals $[3,6,7]$. The adult toad is medium in size, the males slightly smaller than the females with an approximate snout vent length (SVL) of $60 \mathrm{~mm}$ in males and $69 \mathrm{~mm}$ in females [1]. Its appearance is bufoniform, with long and robust limbs and webbed hind legs with a thick interdigital membrane. The back is covered with numerous protrusions and in the area of the head it has a pair of large and protruding parotid glands. The color pattern corresponds to the diagnostic trait in this species and is mainly used to

(c) The Author(s). 2021 Open Access This article is licensed under a Creative Commons Attribution 4.0 International License, which permits use, sharing, adaptation, distribution and reproduction in any medium or format, as long as you give

appropriate credit to the original author(s) and the source, provide a link to the Creative Commons licence, and indicate if changes were made. The images or other third party material in this article are included in the article's Creative Commons licence, unless indicated otherwise in a credit line to the material. If material is not included in the article's Creative Commons licence and your intended use is not permitted by statutory regulation or exceeds the permitted use, you will need to obtain permission directly from the copyright holder. To view a copy of this licence, visit http://creativecommons.org/licenses/by/4.0/. 
identify it. The characteristic coloration is dark brown to purple; the granulations are covered with spots ranging from red to yellow, with yellow-orange supraocular spots. The belly is black with some yellow-orange spots. It has protruding eyes with a vertical pupil and an invisible tympanic ring $[1,7]$.

Since there are few records of this species, $T$. venustus is considered an endangered species by the IUCN Red List of Threatened Species (IUCN) [9] and Reglamento de clasificación de Especies, Ministerio del Medioambiente (RCE) [10]. Its main threats are its restricted distribution mainly due to a combination of habitat loss, alteration of the Nothofagus forests where habitat, as well as the introduction of predators such as rainbow trout in the streams where it inhabits $[5,9]$.

The best known the population correspond to recorded this in Reserva Altos de Vilches. The type locality (Ralco) has disappeared, having been flooded by a dam of the hydroelectric power station $[3,5]$. The last published record reports the presence of this amphibian in the Parque Nacional Radal Siete Tazas, through the description of two adult individuals, one of which was found dead on a slope. This record extended its distribution range to the northern limit [4].

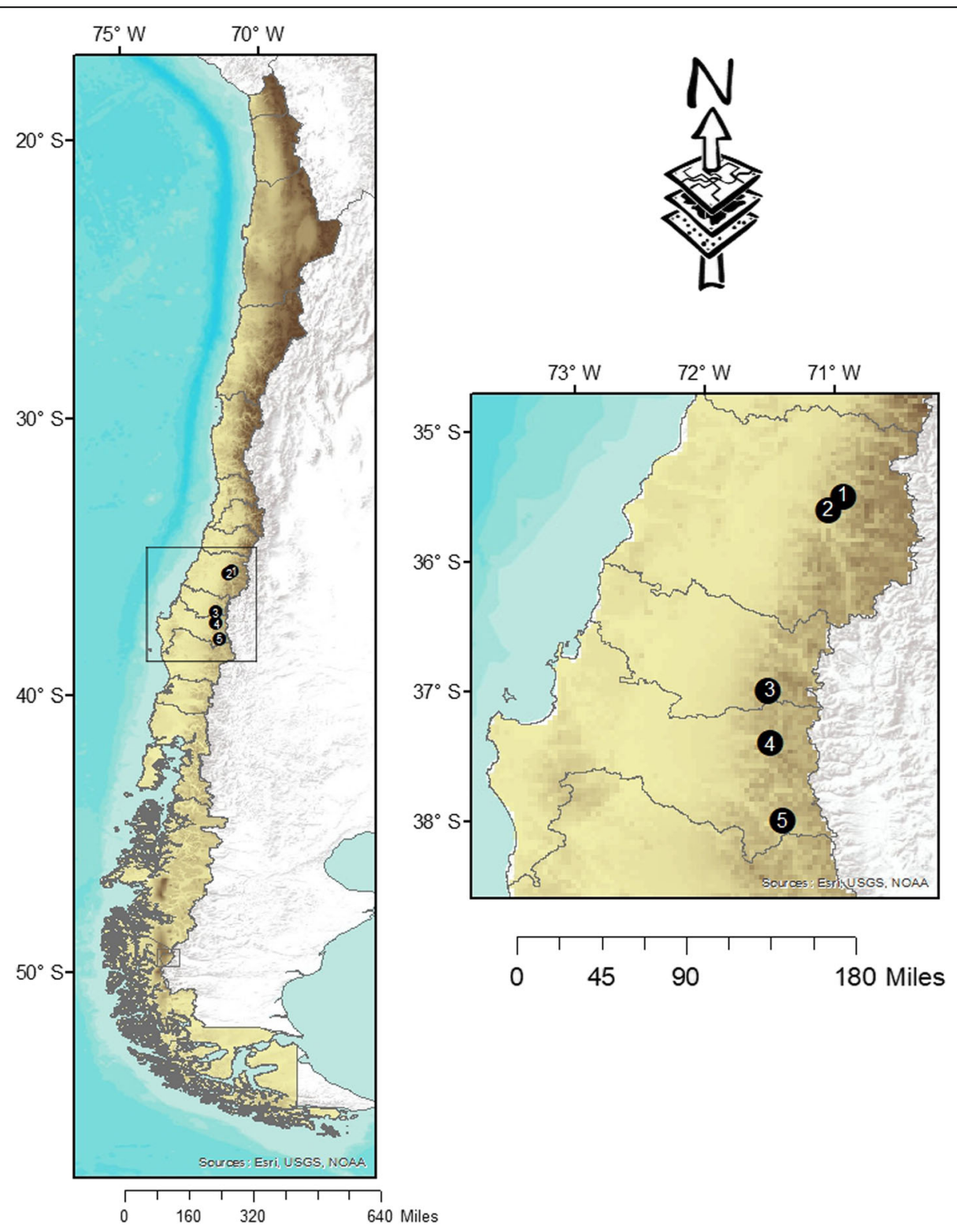

Fig. 1 Distribución geográfica de Telmatobufo venustus. (1) Parque Nacional Radal Siete Tazas (2) Altos de Vilches, (3) Cordillera de Chillán (lugar indeterminado), (4) Altos de Malalcura. (5) Ralco. Geographic distribution of Telmatobufo venustus. (1) Parque Nacional Radal Siete Tazas (2) Altos de Vilches, (3) Cordillera de Chillán (undetermined location), (4) Altos de Malalcura. (5) Ralco 
Here we report the presence of $T$. venustus in the rocky bed of a small mountain stream at $1062 \mathrm{~m}$ in the sector of Altos de Malalcura, Cajón de las Pulgas, in the commune of Antuco, Province of Biobío. We used a Garmin Etrex 30 Global Positioning System (GPS) (37 23.'6.18"S, $71^{\circ} 29^{\prime} 45^{\prime \prime} \mathrm{W}$ ) and ArcMap 10.5 software (Fig. 1) to georeference the record. The individuals encountered and the characteristics of their habitat were recorded in field conditions with a professional Canon sx 70hs camera.

The record is from February 18, 2021; the individuals were found during the day. Three metamorphic individuals were found, of about $41 \pm 1 \mathrm{~mm}$ length from the snout to the end of the remnant of the tail. The toads were found on the side of the stream under small stones contiguous to waterfalls (Fig. 3a). The stream presented crystalline waters with a temperature of 10 to $12^{\circ} \mathrm{C}$, of moderate slope and with a rocky bottom of little depth and reduced width. There were numerous tadpoles of Alsodes sp. in the stream. These were identified as coinhabitants of the habitat of T. venustus.

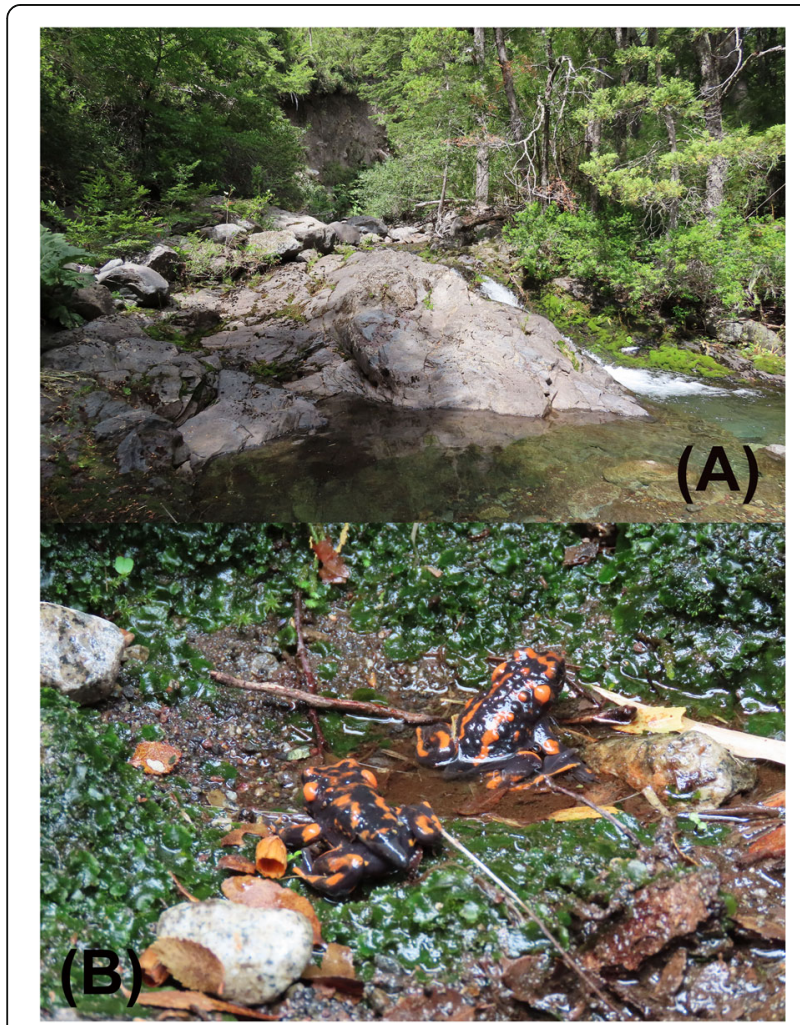

Fig. 2 a Hábitat de T. venustus en sector Altos de Malalcura, corresponde a una zona de pendiente suave y aguas lóticas con temperaturas de 10 a $12{ }^{\circ} \mathrm{C}$ en verano. $\mathbf{b}$ Los individuos fueron encontrado bajos rocas sobre sustrato de Briophytas y Hepáticas. a Habitat of $T$. venustus in Malalcura, corresponds to an area with a gentle slope and lotic waters with 10 to $12^{\circ} \mathrm{C}$ in summer. b The individuals were found under rocks on Bryophyte and Hepatic substrate
The habitat corresponds to the Mountain Deciduous Forest vegetation formation [11], with individuals of Nothofagus dombeyi, Laurelia sempervirens, Lomatia dentata, L. hirsuta, Maytenus boaria, Luma apiculata, Sophora macrocarpa, understory of Chusquea quila, Fuchsia magellanica and abundant Gunnera tinctoria, among other species (Fig. 2).

$T$. venustus has been described as solitary and scarce, so the present record not only broadens its distribution in the Biobío Region, but also shows the presence of a population that could be more abundant, since three metamorphic Gosner 45 stage [12] were observed occupying the same shelter (Fig. 3b). It is likely that this area corresponds to a breeding site, since metamorphic individuals and abundant tadpoles of Alsodes sp. It should be noted that due to the disappearance of the habitats of this species, this record becomes more relevant.

All the individuals presented the typical dark coloration; two had orange spots and one had yellow tones. All the individuals were in the metamorphic state with evident traces of the larval tail (Fig. 3c); no larvae or adults were observed. The area is far from the populated sectors and is an area of private land which is used for ecotourism and adventure sports purposes. However, the place where were recorded is difficult to access, so it seems that the population should not present threats of an anthropic nature. Given the importance of this record

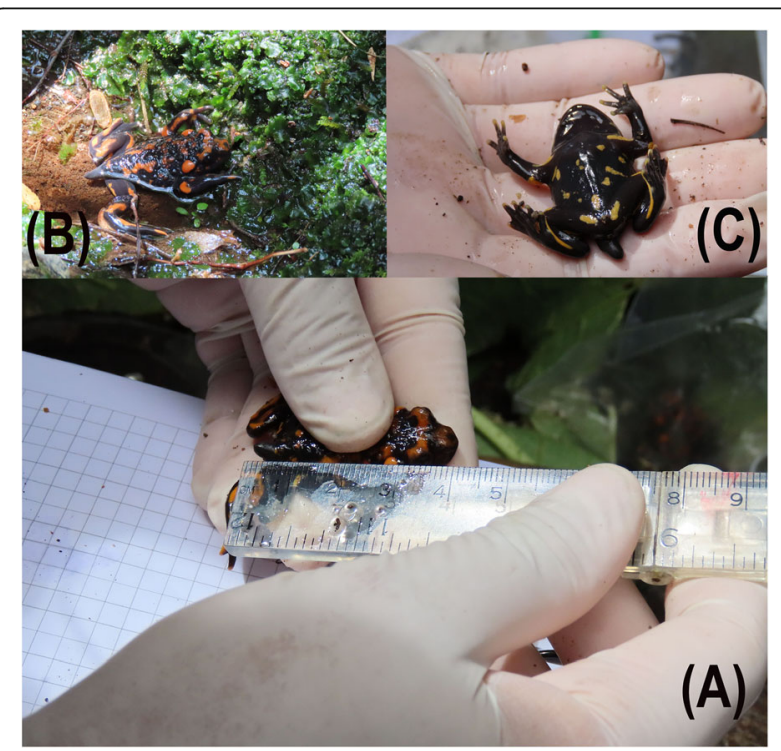

Fig. 3 a Metamorficos de T. venustus, con tamaños de entre 40 a 42 $\mathrm{mm}$ desde el hocico a cloaca. b Individuo metamórfico estado 45 de Gosner, con cola en reabsorción. c El vientre de tonos café oscuro con algunas manchas, variante en tonos amarillo. a Metamorphic $T$. venustus, with sizes between 40 and $42 \mathrm{~mm}$ from the snout to vent. b Metamorphic individual Gosner 45 stage, with a reabsorbed tail. c The belly of dark brown tones with some spots a variant in yellow tones 
for the species, which had not been recorded in the Biobío region in recent decades (from 1983), further prospecting is suggested and maintaining the conditions of its habitat for its conservation in situ, which is not part of a State-protected area.

\section{Abbreviations}

SVL: Snout vent length in millimeters; GPS: The Global Positioning System; IUCN: International Union of Conservation of Natura; RCE: Reglamento de clasificación de Especies. Ministerio del Medioambiente; ${ }^{\circ} \mathrm{C}$ : temperature in degrees Celsius; $37^{\circ} 23$. 6.18 $^{\prime \prime} \mathrm{S}, 71^{\circ} 29^{\prime} 45^{\prime \prime} \mathrm{W}$ : Global position of study area in degrees, minutes and seconds

\section{Acknowledgments}

The authors thank A Jose Castro and Matilda Castro for their support in the field, and Hernán Acuña for allowing access to his property where the presence of the species under study was recorded. Lafayette Eaton for correcting the manuscript.

\section{Authors' contributions}

Data analysis: HD-P. Manuscript preparation: HD-P, NA. All authors read and approved the final version of the manuscript.

\section{Availability of data and materials}

The data sets used in the current study are available from the corresponding author upon reasonable request.

\section{Declarations}

Ethics approval and consent to participate

Not applicable.

\section{Consent for publication}

Not applicable.

\section{Competing interests}

The authors declared that they have no competing interests.

\section{Author details}

'Laboratorio de Ecofisiología y Conservación de Herpetozoos, Departamento de Ciencias Básicas, Escuela de Educación, Universidad de Concepción, Campus Los Ángeles. Casilla 341, Los Ángeles, Chile. ${ }^{2}$ Programa de Doctorado en Sistemática y Biodiversidad, Departamento de Zoología, Facultad de Ciencias Naturales y Oceanográficas, Universidad de Concepción, Campus Concepción, Casilla 160-C, Concepción, Chile.

Received: 17 March 2021 Accepted: 12 May 2021

Published online: 24 May 2021

\section{References}

1. Formas JR, Núñez J, Brieva L. Osteología, taxonomía y relaciones filogenéticas de las ranas del género Telmatobufo (Leptodactylidae). Rev Chil Hist Nat. 2001;74:365-87.

2. Cuevas CC. A new species of Telmatobufo (Anura: Calyptocephalellidae) from a remnant of the Maulino forest, Central Chile. Gayana. 2010;74:10212.

3. Castro-Pastene C, Carrasco H. Herpetozoos de la Reserva Nacional Altos de Lircay, región del Maule, Chile. Bol Museo Nac Hist Nat. 2020;69(1):55-67.

4. Caro-Lagos J, Charrier A. Primer registro de Telmatobufo venustus (Philippi 1899) (Anura, Calyptocephalellidae) en el Parque Nacional Radal Siete Tazas: Ampliación de su distribución geográfica en la Región del Maule, Chile. Bol Chil Herpetología. 2020;7:42-5.

5. Fenolio DB, Charrier A, Levy MG, Fabry MO, Tirado MS, Crump ML, et al. A review of the Chile Mountains false toad Telmatobufo venustus (Amphibia: Anura: Calyptocephalellidae), with comments on its conservation status. Herpetological Rev. 2011;42(4):514-9.

6. Stuart SN, et al. Threatened amphibians of the world. Barcelona/Gland/ Arlington: Lynx Edicions/IUCN/Conservation International; 2008.
7. Díaz N, Sallaberry M, Núñez H. The tadpole of Telmatobufo venustus (Anura: Leptodactylidae) with a consideration of generic relationships. Herpetologica. 1983;39:111-3.

8. Rabanal FE, Nuñez JJ. Anfibios de los bosques templados de chile. Valdivia: Primera edición, Universidad austral de Chile; 2008. p. 206.

9. IUCN. The IUCN red list of threatened species. 2020. https://www.iucnredlist org/.

10. RCE Reglamento de clasificación de Especies. Ministerio del Medioambiente, Chile. 2011. http://especies.mma.gob.cl/CNMWeb/Web/WebCiudadana/ ficha_indepen.aspx? Especield=64\&Version=1.

11. Gajardo R. La vegetación natural de Chile. Santiago: Clasificación y distribución geográfica. Editorial Universitaria; 1994. p. 165.

12. Gosner KL. A simplified table for staging anuran embryos and larvae with notes on identification. Herpetologica. 1960;16:183-90.

\section{Publisher's Note}

Springer Nature remains neutral with regard to jurisdictional claims in published maps and institutional affiliations.
Ready to submit your research? Choose BMC and benefit from:

- fast, convenient online submission

- thorough peer review by experienced researchers in your field

- rapid publication on acceptance

- support for research data, including large and complex data types

- gold Open Access which fosters wider collaboration and increased citations

- maximum visibility for your research: over $100 \mathrm{M}$ website views per year

At BMC, research is always in progress.

Learn more biomedcentral.com/submissions 